\title{
車いす萃引型移動支援装置の試作（その2） \\ Trial manufacture and use appraisal of the wheelchair traction unit
}

\author{
○小林博光 ${ }^{1}$, 片本隆二 ${ }^{1}$, 本田啓一 ${ }^{2}$ \\ 1. 総合せき損センタ一医用工学研究部，2. 株式会社ヘッス \\ OHiromitsu Kobayashi ${ }^{1}$, Ryuji Katamoto ${ }^{1}$ and Keiichi Honda ${ }^{2}$ \\ 1. SPINAL INJURIES CENTER, 2. HEADS Corporation
}

\begin{abstract}
1. はじめに
一般的に、病院や施設内で入院患者が試用や操作練習のた めの十分な数の電動車い寸を用意しているところは極めて少ない。 低下した能力や失われた機能を補完する様々な機械や装置があ るにも関わらす、それらを試すことも知ることもなく、生活していると、 自らの意思で移動する意欲を失ってしまうと危惧している。そこで、 工業用無人搬送車を応用した車い寸星引式移動支援装置を試 作し、昨年の同学会で発表を行った。今回はその続報で、本装 置を病院内でも使用できる形状とし、走行テストを行い、廊下での すれ違いや追い越しの状況を調查した。
\end{abstract}

\section{2. 形状の再者}

前モデルは、工場などの製造現場で用いられる、無人搬送 車のボディをそのまま生かしたものであったため、病院施設 内で利用するには、使用を想定している患者やその家族、病 院スタッフ等にとって受け入れにくい外観であったと考える。

外観の形状を変更するにあたり、駆動ユニット部分のコン パクト化を行った。バッテリやモータの変更に伴い、大幅に 小型化（全長-150 $\mathrm{mm}$ 、全高-175m $\mathrm{mm}$ ) することができた。ただ し、全幅については安全性向上のためのバンパー形状の変更 により $250 \mathrm{~mm}$ 増加した。

コントローラ基盤やタッチパネルディスプレイ、3色パト ライト、撆告メロディモジュールなど、従来モデルと同じ部 品については、そのレイアウトを再考し、省スペースに配置 することとした。

なるべく低コストにできるよう、ボディについては、板金 加工や㰾脂成形により製作することを避け、SUS 社製のアル ミフレームモジュールを利用し、新規作成した駆動ユニット にあわせ製作した。

駆動ユニット部分は加工のしやすさから鉄 (S45C 鋼)を採用して いるが、これを利用して、前述のボディとの接合を磁石ユニットに より実現している。メンテナンス時には工具を使うことなく、大きく 開口させることができるとともに、衝突したときなどは、磁石ユニット 部分から折れ曲がり、衝县を吸収する機能も持つ。バッテリへの 充電時は、アルミ板を固定しているナットを手で回し、外すことで 対忍する。将来的にはワンタッチの脱着を実現したいと考えてい 万

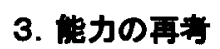

前モデルは、3相 AC200Vモータ $100 \mathrm{~W} 2$ 機使用していたが、 これではオーバースペックである。コストや大きさの面から、DC ブ ラシレスモータ 50Wを2機使用することとした。

商品化と使用現場を鑑み、高額な非接触自動充電方式を採用 せず、一般的な家庭用 $100 \mathrm{~V}$ コンセントを利用する沉用のバッテ リーチャージャーでの充電方法に変更した。あわせて、バッテリむ 国内製の安価なタイプに変更した。

形状の変更にあわせ、テープスイッチを二列に配した円弧状の バンパーに変更した。これにより、斜め方向からの衝突にも有効 に毉急停止できるようになったと考える。また、角張っていないた め、ぶつかった人や物に対しても痛みやダメージを軽減させる効 果も期待できる。

\section{4. 走行实卧}

今回試作した実験用モデルを実際に院内にて走行させ、往来 する人や物について、その数·方向·移動速度の加减速、停止状 況などについて調査した。3m 幅の廊下に $35 \mathrm{~m}$ の磁気テープ(幅 $50 \mathrm{~mm}$ )を直線に配し、6往復の走行を2回(異なる日程)行った。 走行中の平均速度は $13.49 \mathrm{~m} / \mathrm{min}$ である。両端に $2.5 \mathrm{~m}$ の旋回に 必要な部分としたため、実際に車いすを童引している長さは $30 \mathrm{~m}$ となる。終端前 $2.5 \mathrm{~m}$ の地点で停止させて、車い寸と牽引装圈を 介助者が分離させている。

\section{4. 实磁䅦果と青茟}

その結果を Table1に示す。Fig.1は走行実験の様子である。す れ違う人や物が、その移動速度を落とした、あるいは停止したケ 一スは多数あったが、ほとんどが、自身の進行の妨げになるため ではなく、毫引装置自体に興味を持ったためにとった行動のよう である。「れはなんですか?」「ロボットですか?」「連結して電車 ごっこみたいにしたらおもしろそう。」などと、興味を持って話しか ける場面が多数あった。

今回の実験は1時間ほどかけて2度行ったのみであるため、確 定的な結果とは言えないが、おおむね、歩行者の走行の妨げに はなっていないと想像する。

ただし、実験した時閒帯は、患者の食事配䑅台車 (約 $80 \mathrm{~cm}$ ) や移送ベッド(約 $90 \mathrm{~cm}$ )など大型のものの往来がなかったため、 物理的に走行できなかった場面は見られなかったが、配膳台車 やべッドとすれ違う場合には、数 $\mathrm{cm}$ の間隙しか得られないことが わかっている。仮に、これらの大型のものとすれ違う場合には、牽 引装膡側が回避行動をとる必要があると考える。

今後も走行実験を重ねると共に、回避行動についてどのような 手段をとるか、コストとのかねあいも併せて考える予定である。

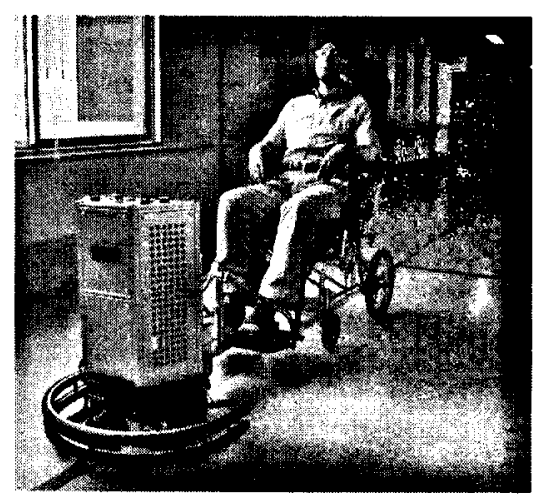

fig. 1 走行実験の様子(搭乗者は著者)

\begin{tabular}{|c|c|c|c|c|c|}
\hline & 通い西かれ & すれ洞った & 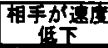 & 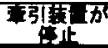 & 相手が侓止 \\
\hline 歩行竟 & 18 & 78 & $\overline{3}$ & 1 & 3 \\
\hline 手勘草いす & 6 & 3 & 1 & 1 & 5 \\
\hline 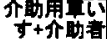 & 4 & $?$ & 3 & 1 & \\
\hline 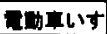 & & $\overline{2}$ & & & \\
\hline 步行橉 & & 3 & 1 & & \\
\hline その他 & & 2 & & 7 & 1 \\
\hline
\end{tabular}

Tabele1 実験結果 